\title{
Thoron in the environment and its related issues
}

\author{
Shinji Tokonami \\ National Institute of Radiological Sciences, 4-9-1 Anagawa, Inage-ku, Chiba 263-8555, Japan \\ E-mail : tokonami@nirs.go.jp
}

\begin{abstract}
Since radon is internationally noted as the second cause of lung cancer, many countries are trying about to solve the problem worldwide. In addition, a new evidence of lung cancer risk has been recently found out with a low level below $200 \mathrm{~Bq} \mathrm{~m}^{-3}$. Thus the action level will have to be set lower than before. Importance of radon exposure has been further recognized and accurate radon concentrations will be required. Recently thoron has also been recognized from the viewpoint of accurate radon measurements. The present paper describes specification of the NIRS radon and thoron chambers, passive measurement technique of radon and thoron and thoron interference on radon measurements from both experimental studies and field experiences on epidemiological study area.
\end{abstract}

Keywords : Radon, thoron, measurement, exposure, lung cancer, epidemiology.

PACS No. : 23.60.+e

\section{Introduction}

Over the past 30 years, radon $\left({ }^{222} \mathrm{Rn}\right)$ has been recognized to be one of the most important contributors to natural radiation sources [1]. Subsequently recent studies have revealed that there is a clearly positive relationship between indoor radon concentration and lung cancer risk even at the low exposure level below $200 \mathrm{~Bq} \mathrm{~m}^{-3}[2,3]$. Thus the WHO launched the International Radon Project in January, 2005. In this project, radon is regarded as the global burden of disease and the second leading cause of lung cancer followed by tobacco smoking. Many countries are about to solve the problem worldwide. In general, residential radon is regulated by the action level with 200-600 $\mathrm{Bq} \mathrm{m}^{-3}$ of radon concentration based on the ICRP recommendation [4]. On the other hand, the WHO is planning to recommend a new guideline of radon exposure. The action level will be revised with a lower level $\left(100-400 \mathrm{~Bq} \mathrm{~m}^{-3}\right)$ than before. From such international circumstances, importance of radon issues has been recognized again. If the new guideline is set up, an indoor radon survey will be definitely initiated. Although radon concentrations are to be measured in this survey, measurement data have to be sufficiently assured from the viewpoint of their reliability. 
For radon measurements, there are many radon measuring devices: alpha track detectors, charcoal canisters, electrets and so on. In particular, alpha track detectors and electrets are suitable for large-scale and long-term surveys so as to obtain annual radon concentrations. Those detectors are also often used in some epidemiological studies. They are generally calibrated in a well-controlled environment such as a radon chamber. They give us radon signals only because there is radon only in the chamber. However, thoron is also everywhere together with radon. In fact, thoron has not been well studied in the past studies over a long time because it was often considered that thoron was much less than radon. There are also some difficulties in measurement and calibration. In addition, there have been no epidemiological data on thoron exposure so far. Tokonami (2005) has pointed out that some of alpha track detectors are sensitive to thoron [5]. This finding implies that radon readings will be overestimated and consequently may lead to incorrect estimates of lung cancer risk.

The present paper describes specification of the NIRS radon and thoron chambers, passive measurement technique of radon and thoron and thoron interference on radon measurements from both experimental studies and field experiences on epidemiological study area.

\section{Specification of NIRS radon and thoron chambers}

Figure 1 illustrates an overview of the NIRS radon chamber [6]. It provides a wellcontrolled, air-tight and uniform environment. Since the inner volume is $24.4 \mathrm{~m}^{3}$, a large number of monitoring instruments can be accommodated for calibration, evaluation and intercomparison purposes. The inner wall is made of stainless steel (SUS-304) in order to prevent inhomogeneous deposition or unstable distribution of radon progeny aerosols in air due to electrostatic problems. This walk-in chamber is environmentally controlled for temperature and relative humidity. The temperature and relative humidity can be controlled in the range of 5 to $30^{\circ} \mathrm{C}$ with an error of $0.5^{\circ} \mathrm{C}$, and 30 to $90 \%$ with an

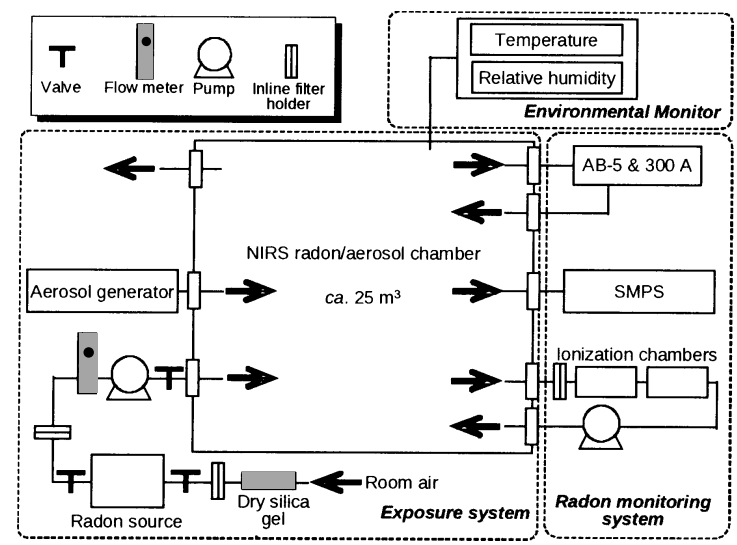

Figure 1. Overview of the NIRS radon chamber. 
error of $3 \%$, respectively. Radon gas is supplied from the ceramic source of ${ }^{226} \mathrm{Ra}$ located outside of the chamber. Radon concentrations are continuously monitored with a scintillation cell and air is intermittently taken with an ionization chamber for checking. Figure 2 exemplifies time variation of radon, temperature and relative humidity in the radon chamber.

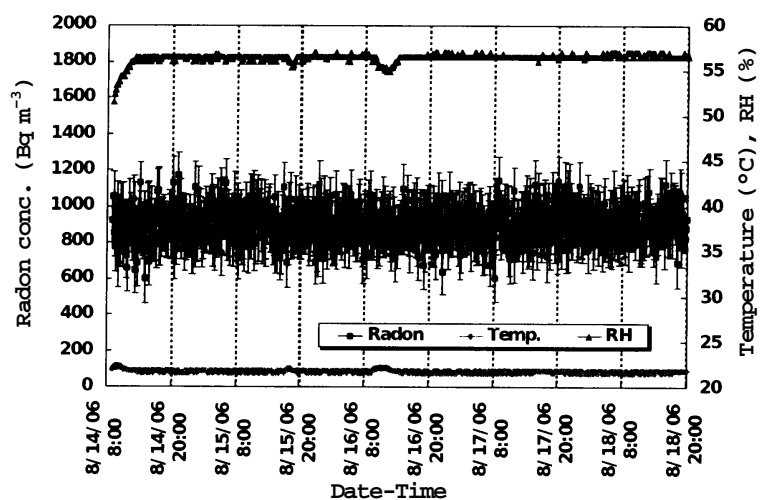

Figure 2. Time variation of radon, temperature and relative humidity in the radon chamber.

Two condensation monodisperse aerosol generators are mounted adjacent to the chamber. Monodisperse aerosols are produced with the evaporation-condensation method. The particle size can be changed with aerosol material as well as the operating parameters - oven temperature, reheater temperature and nitrogen gas flow rate as shown in Figure 3 [7]. Canauba wax is used as the aerosol material because it is solid and its density is $1 \mathrm{~g} \mathrm{~cm}^{-3}$. In the present system, aerosol particles can be produced in the range of 50 to $350 \mathrm{~nm}$.

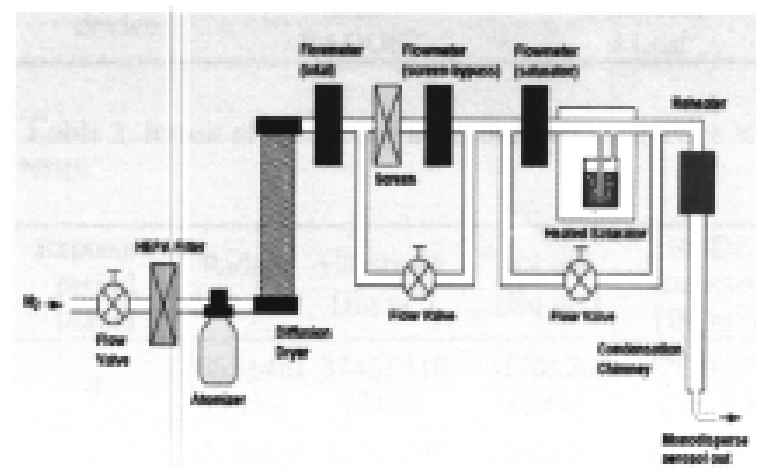

Figure 3. Schematic diagram of the aerosol generator based on the evaporation-condensation method.

In order to continuously measure the aerosol particle size distribution, a SMPS (Scanning Mobility Particle Sizer, TSI Model 3934) is used. The SMPS consists of three main components : an electrostatic classifier Model 3071A, an ultrafine condensation particle counter (UCPC), Model 3025A and a personal computer. The 
present SMPS can measure the particle size distribution approximately from 15 to 700 $\mathrm{nm}$.

Figure 4 illustrates an overview of the NIRS thoron chamber. The chamber consists of four main components : exposure system, calibration system, monitoring system and humidity control system.

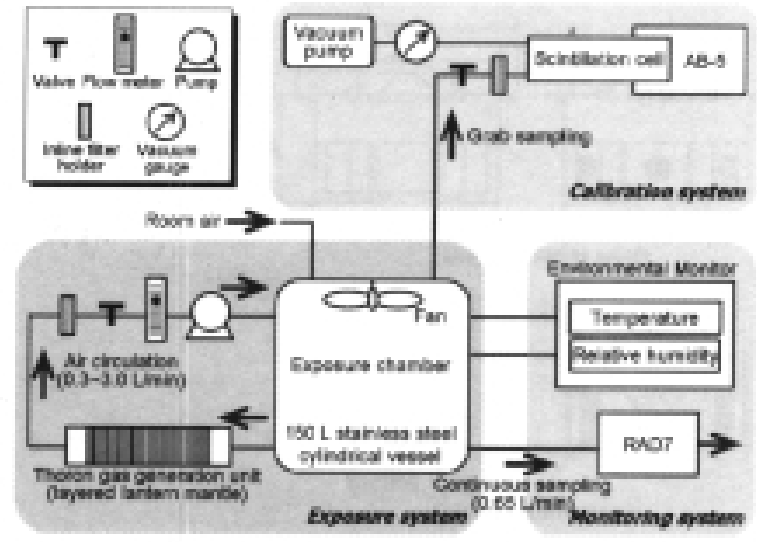

Figure 4. Overview of the NIRS thoron chamber.

The exposure chamber is a 150 liter stainless steel cylindrical vessel and a fan is amounted in the chamber so as to obtain homogeneous distribution of thoron concentration. The thoron gas is supplied through a column filled with many layered lantern mantles with a pump. The thoron concentration is continuously monitored with a RAD7 (electrostatic collection radon monitor). For quality control of thoron concentration, thoron concentrations are accordingly measured with a single scintillation cell technique and grab sampling [8]. Temperature and relative humidity are also continuously monitored. The quality assurance of thoron concentrations are explained as follows : the thoron concentration is determined with the aforementioned single scintillation cell method. Firstly, counting efficiencies for radon and its progeny are calculated by Monte Carlo simulation. Secondly, they are compared with experimental results for their verification. Thus radon concentrations are traceable here. This verified Monte Carlo simulation can be applied to counting efficiencies for thoron and its progeny. Consequently, thoron concentrations can be determined with their counting efficiencies. Figure 5 exemplifies time variation of thoron, temperature and relative humidity in the thoron chamber.

\section{Intercomparison of thoron concentrations between NIRS and NYU}

The intercomparison exercise has been performed between NIRS and NYU (New York Univerisity) for three times. Totally six types of radon monitors were subject to intercompare. The first and third experiments were carried out at NYU in 2004 and 


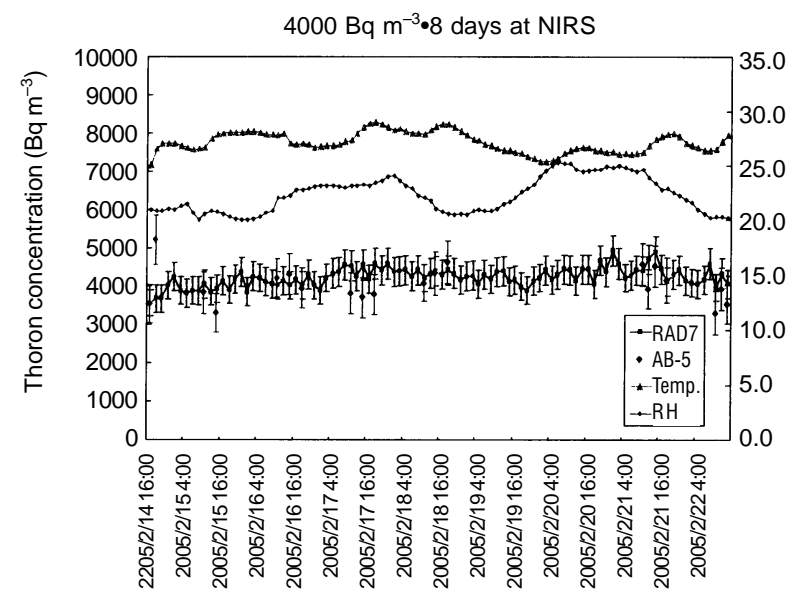

Figure 5. Time variation of thoron, temperature and relative humidity in the thoron chamber.

Table 1. Radon monitors to be intercompared between the two institutions.

\begin{tabular}{ccc}
\hline Affiliation & NIRS & NYU \\
\hline Measuring device & Scintillation cell & Two filter \\
& RAD7 & Ultratrack \\
& RADUET & 4 Leaf \\
\hline
\end{tabular}

2006. Table 1 summarizes the radon monitors to be intercompared between the two institutions. The thoron concentration was set at about $20000 \mathrm{~Bq} \mathrm{~m}^{3}$ and $15000 \mathrm{~Bq}$ $\mathrm{m}^{-3}$, respectively, with four different exposure periods such as $0.75,1,2$ and 3 days. The NYU thoron chamber consists of a 19 liter stainless steel cylindrical vessel with an internal fan as the exposure chamber and a Pylon ${ }^{228} \mathrm{Th}$ solid source as the thoron gas generator. The second intercomparison exercise was carried out at NIRS. The thoron concentration was set at about $4000 \mathrm{~Bq} \mathrm{~m}{ }^{-3}$ with three different exposure periods such as 4,8 and 12 days. There was a good agreement between the two laboratories throughout these three experiments. Table 2 exemplifies the result of the second intercomparison exercise at NIRS.

Table 2. Result of the second intercomparison exercise at NIRS.

\begin{tabular}{ccccc}
\hline $\begin{array}{c}\text { Exposure } \\
\begin{array}{c}\text { period } \\
\text { [days] }\end{array}\end{array}$ & $\begin{array}{c}\text { Raduet } \\
{\left[\mathrm{Bq} \mathrm{m}^{-3}\right]}\end{array}$ & $\begin{array}{c}\text { Ultratrack } \\
{\left[\mathrm{Bq} \mathrm{m}^{-3}\right]}\end{array}$ & $\begin{array}{c}4-\text {-Leaf } \\
{\left[\mathrm{Bq} \mathrm{m}^{-3}\right]}\end{array}$ & $\begin{array}{c}\text { RAD7 } \\
\text { corrected } \\
{\left[\mathrm{Bq} \mathrm{m}^{-3}\right]}\end{array}$ \\
\hline 4 & $3955 \pm 481$ & $3145 \pm 518$ & $4170 \pm 290$ & $4262 \pm 379$ \\
& $(93 \%)$ & $(74 \%)$ & $(99 \%)$ & $(100 \%)$ \\
8 & $4228 \pm 555$ & $3515 \pm 296$ & $4030 \pm 260$ & $4235 \pm 251$ \\
& $(100 \%)$ & $(83 \%)$ & $(95 \%)$ & $(100 \%)$ \\
12 & $3973 \pm 509$ & $2701 \pm 222$ & $3700 \pm 120$ & $3863 \pm 320$ \\
& $(103 \%)$ & $(70 \%)$ & $(96 \%)$ & $(100 \%)$ \\
\hline
\end{tabular}




\section{Passive radon-thoron discriminative detector (RADUET)}

Figure 6 illustrates an overview of passive radon-thoron discriminative detector [9].

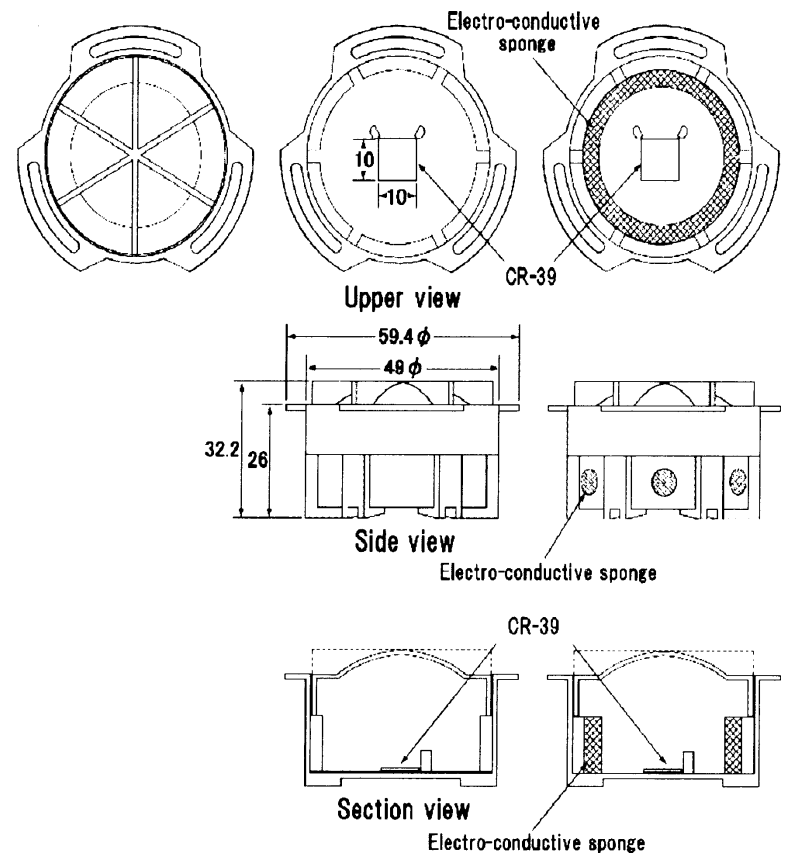

Figure 6. Overview of passive radon-thoron discriminative detector.

The detector consists of two different diffusion chambers. Each chamber is made of an electroconductive plastic and is cylindrical with an inner volume of about $30 \mathrm{~cm}^{3}$. The A CR-39 is used as the detecting material and placed at the bottom of the chamber with sticky clays. Radon in air can penetrate into the chamber through an invisible air gap between its lid and bottom through diffusion. Since this air gap functions as the high diffusion barrier, thoron can scarcely go into the chamber with a small pathway due to its very short half life (55.4 s), compared with that of radon (3.82 d). In order to detect thoron more effectively, six holes of $6 \mathrm{~mm}$ in diameter are opened at the side of the other chamber and are covered with an electroconductive sponge. Since this detector can be mailed into a postbox anywhere with this dimension, an easy and reasonable transportation can be done. The conversion factors are determined by the NIRS radon and thoron chambers.

\section{Thoron interference on radon measurements}

Table 3 summarizes relative sensitivities of typical alpha track-etch detectors.

Some of them were used in the nationwide surveys and epidemiological surveys. In fact, we have some experience on thoron interference on radon measurements in the first nationwide survey in Japan with KfK monitors, conducted from 1985 to 1991 [10]. 
Table 3. Relative sensitivities of typical alpha track-etch detectors

\begin{tabular}{|c|c|c|c|}
\hline \multirow[t]{2}{*}{ Measuring device } & \multicolumn{2}{|c|}{ Sensitivity } & \multirow[t]{2}{*}{ Remarks } \\
\hline & Radon & Thoron & \\
\hline $\begin{array}{c}\text { RADUET } \\
\text { with low air exchange rate }\end{array}$ & 1 & 0.02 & $\begin{array}{l}\text { Tokonami } \\
\text { et al (2005) }\end{array}$ \\
\hline $\begin{array}{c}\text { RADUET } \\
\text { with high air exchange rate }\end{array}$ & 1 & 0.90 & \\
\hline $\begin{array}{c}\text { RADOPOT } \\
\text { with low air exchange rate }\end{array}$ & 1 & 0.05 & $\begin{array}{c}\text { Zhuo } \\
\text { et al (2002) }\end{array}$ \\
\hline $\begin{array}{c}\text { RADOPOT } \\
\text { with high air exchange rate }\end{array}$ & 1 & 0.59 & $\begin{array}{l}\text { Tokonami } \\
\text { et al (2003) }\end{array}$ \\
\hline KfK monitor & 1 & 0.78 & $\begin{array}{l}\text { Tokonami } \\
\text { et al (2001) }\end{array}$ \\
\hline Radtrak & 1 & 0.68 & $\begin{array}{l}\text { Tokonami } \\
\text { et al (2001) }\end{array}$ \\
\hline NRPB/SSI & 1 & 0.05 & $\begin{array}{l}\text { Tokonami } \\
\text { (2005) }\end{array}$ \\
\hline $\begin{array}{l}\text { Radon-thoron discriminative } \\
\text { dosimeterc with low air } \\
\text { exchange rate (Japan) }\end{array}$ & 1 & 0.08 & $\begin{array}{l}\text { Tokonami } \\
\text { et al (2001) }\end{array}$ \\
\hline $\begin{array}{l}\text { Radon-thoron discriminative } \\
\text { dosimeter with high air } \\
\text { exchange rate (Japan) }\end{array}$ & 1 & 0.50 & \\
\hline
\end{tabular}

In field experiences on some epidemiological study area, the thoron interference was obviously found. The indoor radon study on the residential radon and lung cancer risk was conducted in Gansu Province, China, 1994-1998 [11]. This result shows some evidence that residential radon may cause lung cancer. Many dwellings are located at Chinese loess plateau and most people live in caves. In the epidemiological study area, radon measurements were made with Radtrak.

Table 4 summarizes comparison of the survey result with other studies. The previous study gave us high radon concentrations only, but our new survey gave low radon but high thoron concentrations in the same area [12]. Therefore, thoron interference on radon measurements may result in incorrect risk estimates in several epidemiological studies on residential radon. Although former studies might give us low risk estimates, future studies may give us high risk. A new case control study is going on under our control in Gansu Province. 
Table 4. Comparison of the survey result with other studies.

\begin{tabular}{|c|c|c|c|c|}
\hline Items & $\mathrm{NCl}(2002)$ & NIRS (2005) & $\begin{array}{l}\text { Wiegand } \\
\text { et al (2000) }\end{array}$ & NIRS (2004) \\
\hline $\begin{array}{l}\text { Study area } \\
\text { province }\end{array}$ & $\begin{array}{l}\text { Pingliang } \\
\text { Qingyane } \\
\text { Gansu }\end{array}$ & $\begin{array}{l}\text { Qingyane } \\
\text { Gansu }\end{array}$ & $\begin{array}{l}\text { Yan'an } \\
\text { Shaanxi }\end{array}$ & $\begin{array}{l}\text { Yan'an } \\
\text { Shaanxi }\end{array}$ \\
\hline $\begin{array}{l}\text { Radon } \\
\left(\mathrm{Bq} \mathrm{m}^{-3}\right)\end{array}$ & 223 & 92 & $92 a$ & 76 \\
\hline $\begin{array}{l}\text { Thoron } \\
\left(\mathrm{Bq} \mathrm{m}^{-3}\right)\end{array}$ & No data & 354 & $215 a$ & 255 \\
\hline $\begin{array}{c}\text { EETC } \\
\left(\mathrm{Bq} \mathrm{m}^{-3}\right)\end{array}$ & No data & 2.6 & $\begin{array}{c}21.5 b \\
\text { ( } F \text { of } 0.1 \text { used) }\end{array}$ & 2.2 \\
\hline $\begin{array}{c}\text { Excess odds } \\
\text { ratio } \\
\text { (Lung } \\
\text { cancer risk) }\end{array}$ & $\begin{array}{c}0.19 \text { at } 100 \\
\mathrm{~Bq} \mathrm{~m}^{-3} \\
(95 \% \mathrm{Cl}: \\
0.05,0.47)\end{array}$ & On-going & No data & No data \\
\hline
\end{tabular}

\section{Conclusion}

The present study describes thoron in the environment and its related topics. In particular, the following four components are briefly mentioned: specification of NIRS radon and thoron chambers, intercomparison of thoron concentrations between NIRS and NYU, passive radon-thoron discriminative detector (RADUET) and thoron interference on radon measurements from both experimental studies and field experiences in some epidemiological area. Thoron problem still remains unsolved.

\section{References}

[1] UNSCEAR Sources and effects of ionizing radiation (New York : United Nations) (2000)

[2] S Darby, D Hill, A Auvinen, J M Barros-Dios, H Baysson, F Bochicchio, H Deo, R Falk, F Forastiere, M Hakama, I Heid, L Kreienbrock, M Kreuzer, F Lagarde, I Makelainen, C Muirhead, W Oberaigner, G Pershagen, A Ruano-Ravina, E Ruosteenoja, A Schaffrath Rosario, M Timarche, L Tomasek, E Whitley, HE Wichmann and R Doll BMJ doi:10.1136/bmj.38308.477650.63 (2004)

[3] D Krewski, J H Lubin, J M Zielinski, M Alavanja, V S Catalan, R W Field, J B Klotz, E G Le'toumeau, C F Lynch, J I Lyon, D P Sandler, J B Schoenberg, D J Steck, J A Stolwijk, C Weinberg and H B Wilcox Epidemiology 16137 (2005)

[4] ICRP Protection against radon at home and at work ICRP Publication 65 Annals of the ICRP (1993)

[5] S Tokonami High levels of natural radiation and radon areas : radiation dose and health effects, International Congress Series 1276 (eds.) T Sugahara, Y Sasaki, H Morishima, I Hayata, M Sohrabi and S Akiba (London : Elsevier) 151 (2005)

[6] S Tokonami, Y Ishimori, T Ishikawa, K Yamasaki and Y Yamada Jpn. J. Health Phys. 40183 (2005)

[7] http://www.tsi.com/documents/3475.pdf

[8] S Tokonami, M Yang, H Yonehara and Y Yamada Rev. Sci. Instrum. 7369 (2002)

[9] S Tokonami, H Takahashi, Y Kobayashi, W Zhuo and E Hulber Rev. Sci. Instrum. 76113505 (2005) 
[10] S Tokonami, H Yonehara, W Zhuo, Q Sun, T Sanada and Y Yamada 9th Int. Conf. on Indoor Air Quality and Climate (Indoor Air 2002 Proc.) 665 (2002)

[11] Z Wang, J H Lubin, L Wang, S Zhang, J Boice, H Cui, S Zhang, S Conrath, Y Xia and R A Kleinerman Am. J. Epidemiol. 155554 (2002)

[12] S Tokonami, Q Sun, S Akiba, W Zhuo, M Furukawa, T Ishikawa, C Hou, S Zhang, Y Narazaki, B Ohji, H Yonehara and Y Yamada Radiat. Res. 162390 (2004) 